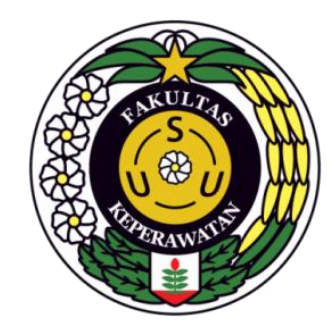

KAJIAN ILMIAH

\title{
PERAN PEMIMPIN DALAM PERKEMBANGAN TEKNOLOGI INFORMASI TELENURSING YANG MENJADI TREND ISU KEPERAWATAN
}

DISUSUN OLEH :

RINI DEBORA SILALAHI (197046015)

rinisilalahi19@gmail.com

PROGRAM STUDI MAGISTER ILMU KEPERAWATAN

FAKULTAS KEPERAWATAN

UNIVERSITAS SUMATERA UTARA 


\title{
PERAN PEMIMPIN DALAM PERKEMBANGAN TEKNOLOGI INFORMASI TELENURSING YANG MENJADI TREND ISU KEPERAWATAN
}

\author{
Rini Debora Silalahi \\ Mahasiswa Magister Keperawatan Fakultas Keperawatan Universitas Sumatera Utara
}

\begin{abstract}
ABSTRAK
Kemajuan teknologi informasi dibidang kesehatan berdampak terhadap tingginya pemahaman masyarakat terhadap dunia kesehatan, sehingga tenaga kesehatan dituntut untuk memberikan pelayanan kesehatan berkualitas, profesional dan mengedepankan perkembangan teknologi dibidang kesehatan itu sendiri. Salah satu bentuk pemanfaatan teknologi informasi dibidang kesehatan adalah penggunaan metode Telenursing. Kajian ini akan membahas definisi telenursing, kelebihan dan kekurangan telenursing serta aplikasinya dalam pelayanan keperawatan. Telenursing sudah sejak lama digunakan dalam pelayanan keperawatan di negara-negara maju, di Indonesia model ini belum berkembang, namun seiring dengan peningkatan perkembangan teknologi informasi di Indonesia terutama tingginya angka penggunaan jaringan internet di Indonesia maka diharapkan Telenursing juga dapat berkembang sebagai trend pelayanan keperawatan di tahun 2020 nantinya. Penelitian-penelitian Telenursing menunjukkan bahwa terdapat peningkatan kepuasan masyarakat terhadap pelayanan kesehatan melalui Telenursing. Dengan kemudahan akses jalur teknologi informasi saat ini pelayanan keperawatan melalui Telenursing menjadi lebih efektif dan efisien, sehingga kualitas dari pelayanan kesehatan yang profesional dapat dirasakan oleh masyarakat.
\end{abstract}

\section{Kata Kunci : Pemimpin, Telenursing, Pelayanan kesehatan}

\section{A. Latar Belakang}

Pengembangan teknologi informasi dan komunikasi mempunyai dampak yang signifikan dalam setiap bagian kehidupan sehari-hari dan telah mendukung aplikasi teknologi informasi dan komunikasi dalam bidang kesehatan. Dengan adanya teknologi informasi dalam bidang keperawatan sehingga muncul metode baru dalam memberikan asuhan keperawatan yang dikenal dikenal dengan telenursing. Telenursing merupakan bagian dari Telehealth yang diterapkan pada keperawatan. Telenursing adalah penggunaan teknologi untuk memberikan asuhan keperawatan dan praktek keperawatan jarak jauh kepada pasien yang bertujuan untuk memperbaiki perawatan kesehatan (Asiri et al, 2016). Sejauh ini dengan menggunakan telepon, aktivitasnya telah sangat meningkat. Berbagai layanan dan teknologi yang dicakup oleh telenursing termasuk konsultasi jarak jauh; pengawasan perawatan diri oleh pasien di tempat tinggal mereka; transfer data yang 
relevan, seperti untuk konsultasi dan penelitian pasien, statistik, atau tujuan lain; dan penyediaan perpustakaan dan basis data elektronik. Ini sangat penting di negara-negara berkembang, melalui fasilitasi pembelajaran jarak jauh (Eren \& Webster, 2017).

Telenursing dapat mengurangi hari rawat di RS sehingga berdampak pada berkurangnya biaya perawatan (efektif dan efisiensi dari sisi biaya kesehatan), mengurangi jumlah kunjungan ke pelayanan kesehatan, peningkatan jumlah cakupan pelayanan keperawatan dalam jumlah yang lebih luas dan merata, dapat dimanfaatkan dalam bidang pendidikan keperawatan (model distance learning) dan perkembangan riset keperawatan berbasis informatika kesehatan dan meningkatkan kepuasan perawat dan pasien terhadap pelayanan keperawatan yang diberikan serta meningkatkan mutu pelayanan perawatan di rumah (home care). Selain itu telenursing juga meningkatkan rasa aman (safety) perawat dan klien (Kumar \& Snooks, 2013).

Pertumbuhan populasi manusia yang semakin tinggi menyebabkan terjadi peningkatan kebutuhan akan perawatan kesehatan dan kurangnya tenaga perawat menjadi masalah penting untuk menemukan cara-cara dimana teknologi informasi dan komunikasi dapat digunakan untuk memenuhi kebutuhan perawatan. Dengan semakin berkembangnya penggunaan internet dan diikuti pula dengan perkembangan dalam dunia kesehatan dan keperawatan sehingga telemedicine, telehealth dan telenursing menjadi alternatif dalam memberikan pelayanan kesehatan dan keperawatan (McLean et al., 2013). Layanan kesehatan khususnya keperawatan jarak jauh dengan menggunakan media teknologi informatika memberikan kemudahan bagi masyarakat (McLean et al., 2013). Masyarakat atau pasien tidak perlu datang ke rumah sakit, dokter atau perawat untuk mendapatkan layanan kesehatan. Waktu yang diperlukan untuk layanan kesehatan juga semakin pendek. Pasien dari dirumah dapat melakukan kontak melalui internet atau telepon video untuk mendapatkan informasi kesehatan, perawatan dan bahkan sampai pengobatan.

\section{B. Tujuan}

Tujuan kajian ini adalah untuk melihat bagaimana peran pemimpin dalam perkembangan teknologi informasi telenursing yang menjadi trend isu keperawatan di masa akan datang. 


\section{Metode}

Kajian ini dilakukan dengan mencari sumber data baik dari jurnal maupun bukubuku yang berhubungan dengan perkembangan teknologi informasi telenursing. Artikel penelitian yang digunakan bersumber dari Repository USU, Google Scholar. Penelusuran dilakukan dengan kata kunci sesuai dengan topik yaitu pemimpin, telenursing, pelayanan kesehatan

\section{Hasil}

Telenursing didefenisikan sebagai perpaduan layanan telekomunikasi dan keperawatan setiap kali ada jarak fisik yang substansial antara perawat atau antara pasien dan perawat (Amudha, Nalini, Alamelu, Badrinath, \& Sharma, 2017). Seorang perawat yang melakukan telenursing tetap menggunakan proses keperawatan untuk mengkaji, merencanakan, mengimplementasikan, mengevaluasi dan mendokumentasikan asuhan keperawatan (Sanderson, 2018). Telenursing juga melibatkan proses pemberian pendidikan kesehatan kepada klien, serta adanya sistem rujukan. Selain itu telenursing juga tetap mengharuskan adanya hubungan terapeutik antara perawat dan klien, dalam telenursing hubungan tersebut dapat terbina melalui penggunaan telepon, internet atau alat komunikasi yang lainnya (Scotia, 2017)

Padila at all (2018) dalam penelitiannya mengungkapkan bahwa dengan adanya perangkat telenursing maka, masalah- masalah terkait penyediaan SDM perawat yang kurang memadai dibeberapa RS dapat teratasi, termaksud didalamanya jika terjadi hal-hal yang tidak dingginginkan seperti terjadinya kejadian luar biasa (KLB), yang tidak bisa meninggalkan ruangan karena pasien membludak, tetap bisa terkoordinir dengan baik dengan adanya sistem telenursing ini sebagai saran komunikasi dan monitoring tindakan keperawatan. Dengan digunakan SIM telenursing, tidak menutup kemungkinan income RS meningkat tajam, lalu akan menambah peningkatan gaji perawat dan tim medis lainnya sehingga akan meningkat pula produktivitas dalam bekerja. 
Dalam hasil penelitian Yang, Jiang, \& Li tahun 2019 mengenai 'Peran Telenursing Dalam Manajemen Pasien Dengan Diabetes' dihasilkan bahwa telenursing, sebagai alat yang berguna untuk pendidikan pasien dan intervensi perilaku, dapat membantu pasien diabetes untuk meningkatkan kontrol glikemik mereka. Hasil penelitian menunjukkan bahwa pada aplisi telenursing di lapangan membutuhkan beragam kompetensi yang dapat disusun menjadi empat kategori: kompetensi profesional, metodologis, personal, dan sosial (Christine, Bettina, Carsten, Martin, \& Thomas, 2016).

\section{E. Pembahasan}

Perawat yang melakukan telenursing harus perawat yang memiliki lisensi yang valid dan terkini. Kategori pelayanan kesehatan yang bisa diberikan melalui telenursing yaitu preventif misalnya pencegahan efek berbahaya dari penyalahgunaan obatobatan, alkohol, layanan gizi, dan survey kesehatan; promotif meliputi pendidikan kesehatan terkait latihan fisik dan kebiasaan diet sehat; kuratif meliputi layanan yang berhubungan dengan pengobatan penyakit misalnya pemeriksaan dan pemberian resep obat, rehabilitatif meliputi layanan tindak lanjut setelah dirawat di rumah sakit dengan penyakit kronis, operasi dll; dan pelayanan khusus meliputi fisioterapi, tes laboratorium, layanan okupasional, layanan kecanduan dan layanan rujukan baik untuk pribadi atau instansi kesehatan atau sesuai dengan keinginan pasien (Hederbergh, 2007; Sharma, 2014).

Telenursing dianggap mampu untuk memperbaiki keadaan. Dimana masyarakat bisa mengakses perawatan kesehatan dengan cara yang mudah dan biaya yang efektif sehingga dapat meningkatkan kesehatan dan kesejahteraan masyarakat. Dengan telenursing perawat bisa memperluas jangkauan, dapat memberikan perawatan kesehatan kapan dan dimana pasien membutuhkannya bahkan dirumah mereka.

Penerapan telenursing memiliki potensi yang besar untuk meningkatkan akses keperawatan, menekan biaya dan meningkatkan hasil akhir dari perawatan kesehatan. Namun peningkatan penggunaan teknologi akan mempengaruhi hubungan perawat dan klien dengan kualitas perawatan. Hubungan perawat dan klien tidak dapat digantikan dengan teknologi. Tetapi pemberian asuhan keperawatan tanpa sentuhan langsung dari 
tangan perawat atau menggunakan telenursing dapat dikatakan sebagai asuhan keperawatan yang legal, karena dalam sistem telenursing perawat menggunakan pengetahuan, keterampilan, pertimbangan dan pemikiran kritis yang tidak bisa dipisahkan dari ilmu keperawatan, yang meliputi penggunaan ilmu keperawatan, pemikiran kritis, dan pengambilan keputusan.

\section{F. Penutup}

Penerapan telenursing memberikan dampak positif terhadap berbagai pihak seperti pasien, perawat dan pemerintah. Namun hal ini harus didukung oleh keterampilan dan pengetahuan perawat itu sendiri. Perawat harus memiliki pengetahuan tentang komunikasi yang cukup dalam penerapan telenursing. 


\section{Daftar Pustaka}

Astuti, Dwi Yurni. (2017). Evaluasi Implementasi Clinical Pathway Sectio Caesarea di RSUD Panembahan Senopati Bantul. Jurnal Medicoeticolegal dan Manajemen Rumah Sakit. Diakses dari http://google.schoolarevaluassiimplementasipdf.

Evans-Lacko, S., Jarret, M., McCrone, P., et al. Facilitators and barriers to implementing clinical care pathways. BMC Health Services Research. 2010;10,182.

Ghai, S., \& Kalyan, G. (2013). Telenursing an emerging innovation in health sector. Scientific Session. Retrieved from http://www.indus.org/healthcare/S ecientific Sessions/Dr. Sandhya Ghai -Telenursing.pdf

Glinkowski, W., Pawlowska, K., \& Kozlowska, L. (2013). Telehealth and telenursing perception and knowledge among university students of nursing in Poland. Telemedicine and E-Health, 84 19(7), 523-529. https://doi.org/10.1089/tmj.2012.0 217

Kuntoro, Agus. (2017). Buku Ajar Manajemen Keperawatan. Yogayakarta: Nuha Medika.

Marquis, Bassie. (2010). Kepemimpinan dan Manajemen Keperawatan. Jakarta: Penerbit Buku Kedokteran EGC.

McEachen, Irene dan Koegh, Jim. (2018). Manajemen Keperawatan Demystified. Yogyakarta: Penerbit Andi.

Meo, M. Y. (2015). Pengembangan Sistem Informasi Manajemen Keperawatan Dengan Integrated Clinical Pathway Untuk Meningkatkan Kualitas Pelayanan. Jurnal Manajemen Keperawatan. Diakses dari google.schoolar kepemimpinan/bahan\%20teknologi.pdf .

Nursalam. (2016). Manajemen Keperawatan. Jakarta: Penerbit Salemba Medika.

Sharma, S. B. (2014). Telenursing - a potential resource in the eHealth agenda of India. Journal of the International Society for Telemedicine and eHealth, 2(1), 19-28. Retrieved from http://journals.ukzn.ac.za/index.ph p/JISfTeH/article/view/44

Simamora, R. H. (2014). Buku Ajar Manajemen Keperawatan. Jakarta: Penerbit Buku Kedokteran EGC.

Simamora, R. H. (2013). Upaya Pembinaan Perawat Di Rumah Sakit Ngesti Waluyo Parakan Temanggung Jawa Tengah. Jurnal Keperawatan Soedirman,8(2).

Simamora, R. H. (2019). Menjadi Perawat yang: CIH'HUY. Surakarta: Kekata Publisher.

Solikhah, Umi. (2011). Kebutuhan Penerapan Teknologi Informasi Keperawatan di Ruang Rawat Anak. Diakses dari http://google.schoolar. Kebutuhanteknologiinfomasikep.

Souza-junior, V. D., Amélia, I., Mendes, C., Mazzo, A., \& Godoy, S. (2016). Application of telenursing in nursing practice: an integrative literature review, 29, 254-260. https://doi.org/10.1016/j.apnr.201 5.05.005 